\title{
Removal of nutrients and organic pollutants from household greywater by phycoremediation for safe disposal
}

\author{
R. M. Mohamed ${ }^{1}$ A. A. Al-Gheethi ${ }^{1}$ (D) S. S. Aznin ${ }^{1}$ - A. H. Hasila ${ }^{1}$ \\ A. A. Wurochekke ${ }^{1}$ - A. H. Kassim ${ }^{1}$
}

Received: 11 October 2016/Accepted: 27 April 2017/Published online: 3 May 2017

(c) The Author(s) 2017. This article is an open access publication

\begin{abstract}
The present study aimed to investigate the potential for application of phycoremediation system using Botryococcus sp. for the treatment of bathroom greywater at village houses. The greywater samples were obtained from four houses. The treatment system was conducted at ambient temperature for 21 days. Botryococcus sp. (Accession No. JQ585723.1) was inoculated into the greywater in a dry mass $\left(0.3 \mathrm{mg} \mathrm{L}^{-1}\right)$. The results revealed high effectiveness of the treatment system. The maximum reduction of biological oxygen demand $\left(\mathrm{BOD}_{5}\right)$ from four types of greywater ranged from 85.3 to $98 \%$, while was between 71.22 and $85.47 \%$ for chemical oxygen demand (COD) after 21 days. The reduction of nitrate $\left(\mathrm{NO}_{3}{ }^{-}\right)$ appeared rapidly within 18 days of the treatment period with $98 \%$ of the reduction efficiency. Reduction of ammonia $\left(\mathrm{NH}_{3}\right)$ and orthophosphate $\left(\mathrm{PO}^{3-}\right)$ was recorded after 21 days with the efficiency ranged from 86.21 to 99 and 39.12 to $99.3 \%$, respectively. The high removal percentage of potassium (K) (97\%) recorded within 3 days, while calcium $(\mathrm{Ca})$ reduction (95\%) was noted at the end of the treatment period indicating the high applicability of phycoremediation system to be used in the village houses. Moreover, the system is easily implementable, very low cost where no energy is required, eco-friendly and has no toxic by-products.
\end{abstract}

R. M. Mohamed

maya@uthm.edu.my

$\square$ A. A. Al-Gheethi

alisaeed@uthm.edu.my

1 Micro-Pollution Research Centre (MPRC), Department of Water and Environmental Engineering, Faculty of Civil and Environmental Engineering, Universiti Tun Hussein Onn Malaysia, Parit Raja, 86400 Batu Pahat, Johor, Malaysia
Keywords $\mathrm{BOD}_{5} \cdot \mathrm{COD} \cdot$ Nutrients $\cdot$ Elements $\cdot$ Growth rate $\cdot$ Malaysia

\section{Introduction}

Greywater is the wastewater generated from household activities such as bathing and washing. The discharge of these wastes represents a major environmental issues due to organic and inorganic components which have adverse effects on the environment and water bodies including eutrophication phenomenon [1]. In the large cities of the developing countries such as Malaysia with high populations, the greywater are discharged with the black water through the sewerage network into the central wastewater treatment plants and then subjected for the treatment process. In the contrast, in the rural area the greywater is discharged separately into the river water. This step is performed to reduce the quantity of sewage which is discharged into the individual septic tank (IST) due to the absence of a central wastewater treatment plant. However, these practices became unacceptable in the recent years due to the decrease in the level of rains which play an important role in the dilution of greywater $[2,3]$.

Unlike arid and semi-arid countries in Middle East and Africa which have water shortage problems, Malaysia has several water resources including seas, lakes, rivers and groundwater. However, the rapid growing population and urbanization in the country since 2000s have increased the pollution levels of the natural water resources. There are more than 17,633 water pollution point sources revealed in Malaysia. About $41 \%$ of water resources in Malaysia contain high concentrations of total suspended solid (TSS) and biochemical oxygen demand $\left(\mathrm{BOD}_{5}\right)$ than that recommended by EQA 1974 regulations. Hence, a crucial step 
has to be taken in Malaysia to improve the water bodies and then to become a fully developed nation by the year 2020. Malaysia has been adopted a practical, economical and acceptable approach in managing and disposing sewage treated effluents since 1970s. There are two standards for treatment of sewage effluents: EQA1974, Regulation 2009 (Sewage) which are Standard A and Standard B (DOE 2010). However, the national guideline for greywater has not yet regulated [4].

Among 28 million of population equivalent (PE) in Malaysia, about 9 million people $(33 \%)$ standing in the villages. Therefore, the huge quantities of the greywater are generated from these villages. Moreover, there is no plan to build wastewater treatment plants at rural area in Malaysia. For this reason, the peoples used individual septic tanks as a primary treatment process of sewage. It is estimated that there are over 1 million individual septic tanks in Malaysia [5]. In contrast, the greywater are disposed to the river waters without treatment which increase the natural water bodies' pollution. Therefore, the village houses with the absence of public treatment must depend on treatment process to treat their greywater before the discharge into the environment. The presence of a small treatment system of greywater prior to discharge into the main drain with high efficiency and low cost might reduce the pollutants in the greywater [3].

The efficiency of phycoremediation using different microalgae species as a treatment technology for several types of wastewater such as greenhouse, brewery and dairy wastewater has been reported in the literature. It has been occurred high effectiveness to enhance the quality of wastewater because they have overgrowth in these wastes [6]. The main consideration in the phycoremediation process is to use indigenous strains which have the ability to survive and compete with other indigenous microorganisms in the greywater such as bacteria. Botryococcus braunii, Scenedesmus dimorphus, Spirulina sp., Chlorella vulgaris and Phormidium sp., have high effectiveness because they have the ability to tolerate hard environmental conditions [7]. One of the effective techniques to improve the phycoremediation efficiency is using starved microalgae, in which the activated algae is obtained from the sludge thickness stage where hyper-concentrated algal cultures are available, and then subject to the starvation process by the drying at room temperature. Utilization of microalgae which have already adapted to hard environmental conditions might improve the phycoremediation process to be more effective, even during colder periods [8]. Besides, the starvation process induces the microalgae to produce the resting cysts due to the deficiency in the nutrients and has high potential to survive in a dormant state in unfavorable conditions for long period [9]. These cells grow rapidly after the inoculation into the greywater with high nutrients and then accelerate the nutrients removal within a very short period of time. Moreover, this method is a good option to decrease the land and space requirements; thus, the phycoremediation process was performed in an individual tank for each house and this is to emphasize the novelty of the present study.

The current work aimed to design a phycoremediation system of greywater to be applied for each individual village house. The potential of starved Botryococcus sp. inoculated into the system tank to improve the parameters of greywater before the discharge into the environment was investigated. These parameters included BOD, COD, nutrients (total nitrogen and total phosphorus) as well as elements.

\section{Materials and methods}

\section{Study area}

The present study was focused on a village located at Parit Raja (20 km from Batu Pahat, Johor Malaysia) because the discharge of greywater into the main ditch is common practice among the village community. These practices increase the spreading infectious agents and provide a breeding environment for insect pests [3, 4].

\section{Estimation of raw greywater quantity}

The gathering information which including the occupants number and age as well as the households activities of four houses were collected during the interview and a using survey data form. These houses belong to families with eight adults, four children and two babies. The quantity of greywater generated from village houses was estimated using bucket method as described by Mohamed et al. [3]. The quantities of greywater were estimated in the period between November and December 2015 and within 24 h, $7 \mathrm{am}$ to $12 \mathrm{pm}, 12 \mathrm{pm}$ to $6 \mathrm{pm}$, and from $6 \mathrm{pm}$ to $7 \mathrm{am}$. The time selected represents the peak bathing period and ensures that the collected samples reflect the actual constitutes of the greywater.

\section{Greywater sampling}

Plastic bottle polyethylene terephthalate (PET) bottles $(5 \mathrm{~L})$ were used for the collection of greywater samples $(5 \mathrm{~L})$. The samples were collected from the discharge point of greywater at each house. The mouth of the tap was disinfected with cotton wool soaked in ethanol to prevent the contamination. The tap was allowed to run for few minutes; the container was rinsed three times with greywater before collection of the final sample. The samples 
were kept in an ice box while transporting to wastewater laboratory at Universiti Tun Hussain Onn Malaysia (UTHM). The preservation of greywater samples was carried out according to APHA [10].

\section{Microalgae strain}

An indigenous strain of Botryococcus sp. (Accession No. JQ585723.1) was obtained from freshwater. It was identified using molecular analysis based on the $18 \mathrm{~S}$ rRNA sequencing (Table 1). A pure culture of Botryococcus sp. was sub-cultured on Bold Basal medium and then sent to Axil Scientific Pte Ltd. for the identification purpose. Botryococcus sp. was acclimatized to grow in greywater by sub-culture in greywater and incubation for 1 month. This step was repeated three times; the occurrence of overgrowth during the third subculture indicates the ability of microalgae to grow in these waters. Thereafter, Botryococcus sp. was subjected for starvation process. In this experiment, pure culture of Botryococcus sp. was sub-cultured in greywater medium and then incubated at $25-29^{\circ} \mathrm{C}$ for 1 month $(12 \mathrm{~h} \mathrm{~L}$ : $12 \mathrm{~h} \mathrm{D}$ period) [11]. The microalgae cells were harvested from the medium using centrifugation process (4020 rcf), washed three times with sterilized deionized water to remove the media residues. The microalgae cells were placed in a sterilized glass bottle and left at room temperature for 1 month. The ability of microalgae to survivability during the starvation process (every 10 days) was tested by culture-based method; a loopful of the microalgae biomass was subcultured into a Bold Basal broth medium to observe the growth. To prepare the microalgae inoculum, $1 \mathrm{mg}$ of microalgae cells was suspended in $10 \mathrm{~mL}$ of sterilized normal saline water, then a fixed volume of $(1 \mathrm{~mL})$ the suspension was taken for counting using haemocytometer as described by APHA [10]. The weight of microalgae cells used as inoculum $\left(0.3 \mathrm{~g} \mathrm{~L}^{-1}\right)$ was calculated to be equivalent to $10^{6}$ cell $\mathrm{mL}^{-1}$.

\section{Experimental set up}

Factorial complete randomized design $(\mathrm{CRD})(5 \times 8 \times 9)$ in triplicate was used to study the efficiency of photo-reactor design here with Botryococcus sp. for improvement of greywater characteristics, where: four photoreactor tanks (one for each house), and one (1) control for the phycoremediation process making a total of five groups. Eight interval periods $(0,3,6,9,12,15,18$ and 21) and nine dependent variables including $\mathrm{pH}, \mathrm{BOD}_{5}, \mathrm{COD}, \mathrm{NO}_{3}{ }^{-}$, $\mathrm{PO}_{4}{ }^{3-}, \mathrm{NH}_{2}, \mathrm{Na}, \mathrm{Ca}$ and $\mathrm{K}$ ions were tested after each interval period and for each phycoremediation Tank.

\section{Phycoremediation system operation}

The phycoremediation treatment system used in the current study was designed for laboratory scale (Fig. 1). The system consisted of three tanks ( $5 \mathrm{~L}$ of each) including storage tank, control tank (Tank I) and phycoremediation tank (Tank II). Storage and control tanks were made up of opaque PVC to prevent the photo-degradation of nutrients, while tank II was made up of transparent PCV to allow light to penetrate through the greywater and induce the microalgae growth. The storage tank was used to composite and storage of the samples collected in the morning and evening as well as to clarify the greywater by natural sedimentation of insoluble solid materials. The storage tank was connected to tank (I) via a PVC pipe (3 mm of diameter) with water valve fixed on $5 \mathrm{~cm}$ of the tank surface. The greywater generated from the house was passed through the membrane filter to remove the suspended solids and stored in the storage tank and lastly to the tank I and tank II with $20 \mathrm{~mL} \mathrm{~min}^{-1}$ of flowrate. Moreover, no sterilization process was conducted for the greywater to

Table 1 Accession number of Botryococcus sp.

\begin{tabular}{|c|c|c|c|c|c|c|}
\hline Description & $\begin{array}{l}\text { Max } \\
\text { score }\end{array}$ & $\begin{array}{l}\text { Total } \\
\text { score }\end{array}$ & $\begin{array}{l}\text { Query } \\
\text { cover } \\
(\%)\end{array}$ & $\begin{array}{l}\mathrm{E} \\
\text { value }\end{array}$ & $\begin{array}{l}\text { Ident } \\
(\%)\end{array}$ & Accession \\
\hline Botryococcus sp. AP101 18S ribosomal RNA gene, partial sequence & 985 & 985 & 45 & 0.0 & 92 & JQ585723.1 \\
\hline Botryococcus braunii strain KMRR $18 \mathrm{~S}$ ribosomal RNA gene, partial sequence & 981 & 981 & 45 & 0.0 & 92 & KU678200.1 \\
\hline $\begin{array}{l}\text { Botryococcus braunii strain AICB } 5318 \mathrm{~S} \text { ribosomal RNA gene, partial sequence; } \\
\text { internal transcribed spacer } 1,5.8 \mathrm{~S} \text { ribosomal RNA gene, and internal transcribed } \\
\text { spacer } 2 \text {, complete sequence; and } 28 \mathrm{~S} \text { ribosomal RNA gene, partial sequence }\end{array}$ & 957 & 1606 & 81 & 0.0 & 91 & JF261250.2 \\
\hline $\begin{array}{l}\text { Botryococcus braunii genomic DNA containing 18S rRNA gene, ITS1, 5.8S rRNA } \\
\text { gene, ITS } 2 \text {, culture collection CCAP } 807 / 2\end{array}$ & 957 & 1642 & 82 & 0.0 & 91 & FR865761.1 \\
\hline Botryococcus sp. Tow 9/21 P-16w $18 \mathrm{~S}$ ribosomal RNA gene, partial sequence & 957 & 1664 & 83 & 0.0 & 91 & AY197640.1 \\
\hline $\begin{array}{l}\text { Botryococcus braunii strain AICB } 85918 \mathrm{~S} \text { ribosomal RNA gene, partial sequence; } \\
\text { internal transcribed spacer } 1,5.8 \mathrm{~S} \text { ribosomal RNA gene, and internal transcribed } \\
\text { spacer } 2 \text {, complete sequence; and } 28 \mathrm{~S} \text { ribosomal RNA gene, partial sequence }\end{array}$ & 952 & 1592 & 81 & 0.0 & 90 & JF261269.2 \\
\hline
\end{tabular}




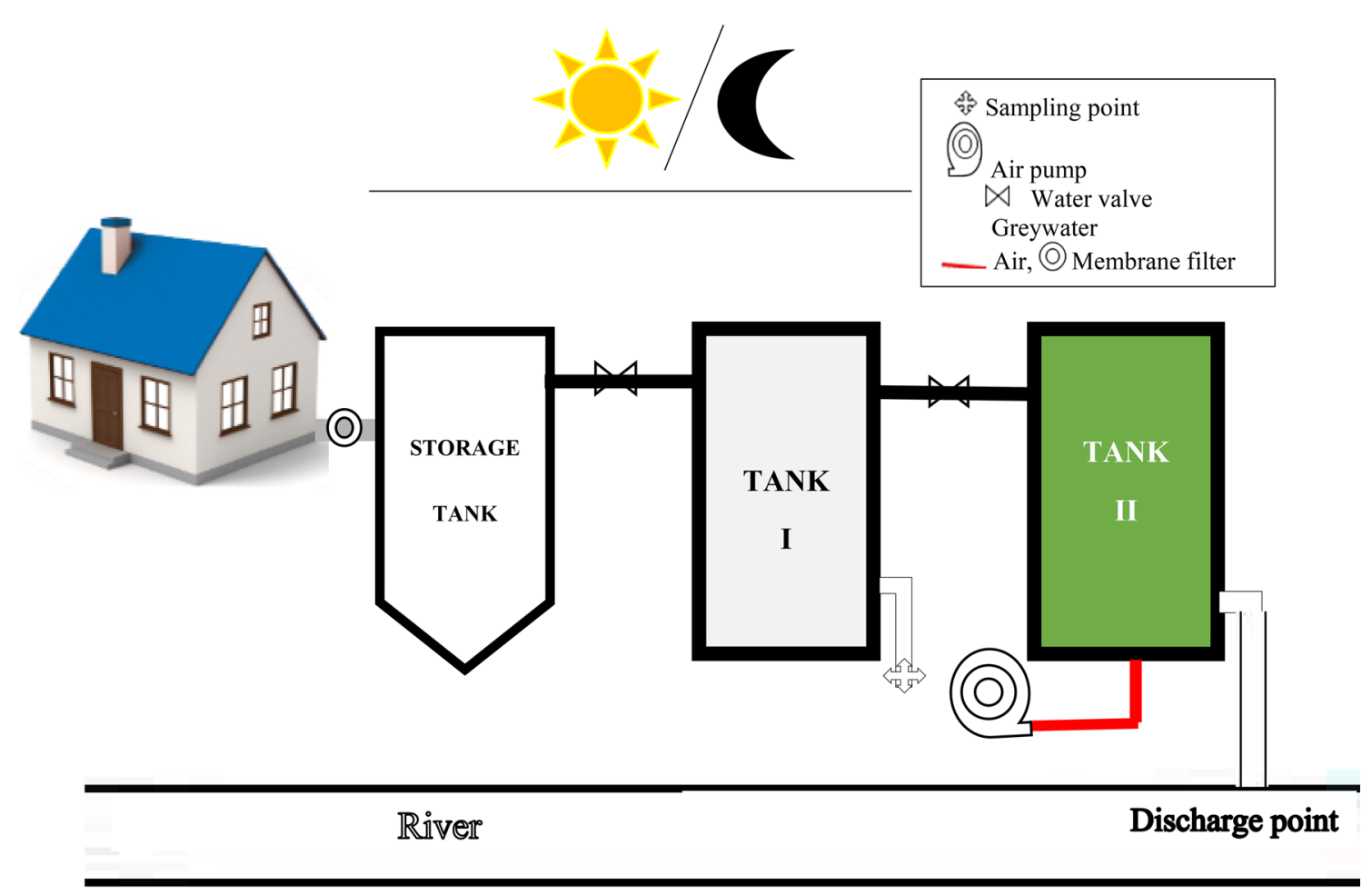

Fig. 1 Scheme of the photo-reactor system; Tank I (Control); Tank II (inoculated with Botryococcus sp.)

test the efficiency of phycoremediation process when it be applied onsite. After installing the treatment system, the water valve fixed on tank (I) was opened to fill up tank (II) with $4 \mathrm{~L}$ of greywater. The tank was inoculated with fixed weight of Botryococcus sp. cells $\left(0.3 \mathrm{~g} \mathrm{~L}^{-1}\right)$ (equivalent to $10^{6}$ cell $\mathrm{mL}^{-1}$ ). The tank was covered with loose woven cloths (cheesecloth) to prevent outside contamination. Air pump was used to provide air required to improve the microalgae growth as well as to prevent the sedimentation process of the microalgae biomass generated during the phycoremediation process. The control tank was conducted without Botryococcus sp. inoculation. The phycoremediation process was performed at ambient temperature and sunlight for 21 days with $18 \mathrm{MJ} \mathrm{m}^{-2}$ day $^{-1}$ of solar intensity according to the Malaysian Meteorological Department (MMD) and Ministry of Science, Technology and Innovation (MOSTI). The characteristics of raw greywater and that generated from the control and phycoremediation tank were determined for each length of the phycoremediation period $(0,3,6,9,12,15,18$ and 21 days) as described below. Botryococcus sp. growth during the phycoremediation process was tested daily in comparison to the growth in Bold Basal broth medium.

\section{Analytical methods}

The tested parameters of greywater which included total suspended solid (TSS), chemical oxygen demand (COD), biochemical oxygen demand $\left(\mathrm{BOD}_{5}\right)$, turbidity, $\mathrm{pH}$ values, nitrate $\left(\mathrm{NO}_{3}{ }^{-}\right)$, orthophosphate $\left(\mathrm{PO}_{4}{ }^{3-}\right)$, ammonia $\left(\mathrm{NH}_{2}{ }^{-}\right)$, sodium (Na), calcium (Ca) and potassium (K) were determined according to APHA [10]. $\mathrm{pH}$ value was measured by $\mathrm{pH}$ meter (Hach 51750-60 Sension 3); COD was by using closed reflux method (method 8000 ; HACH DR 6000); BOD was determined by 5-day incubation test at $20^{\circ} \mathrm{C}$; TSS was estimated by the photometric method (method 430, HACH DR6000), Turbidity was determined by Attenuated Radiation Method (Direct Reading) (HACH 2100N Turbidi meter); $\mathrm{Na}, \mathrm{Ca}$ and $\mathrm{K}$ metals were determined using Atomic Absorption Spectrometer (Perkin Elmer Analyst 800). Nutrients including nitrate $\left(\mathrm{NO}_{3}{ }^{-}\right)$, phosphorus $\left(\mathrm{PO}_{4}{ }^{3-}\right)$, ammonia $\left(\mathrm{NH}_{2}{ }^{-}\right)$ were determined using ion chromatography system (IC) (ICS-2000).

The comparison between greywater parameters before and after the phycoremediation process was carried out to determine the percentage removal pollutant and water quality standards before the discharge to the main channel or river nearby. The result of analysis data was compared to EQA 1974, Regulations 2009.

The parameters removal efficiency by Botryococcus sp. during phycoremediation period were calculated using Eq. (1) according to Larsdotter et al. [12].

Removal percentage $(\%)=\frac{\left(N_{0}-N_{i}\right)}{N_{0}} \times 100 \%$, 
where $N_{0}$ is the constituent amount at the initial experiment; $N_{i}$ is the constituent amount at the desired time.

The significant differences among the removal efficiencies were analyzed using one-way analysis of variance (ANOVA, $P<0.05$ ) (SPSS Inc.).

\section{Results and discussion}

\section{Quantity of greywater from village houses}

Quantity of greywater and household activities of the village houses at study area were conducted to design an effective phycoremediation system. The summary for the information obtained by interview and questionnaire is presented in Table 2. Four houses were selected to represent a small model of the village houses. The children age ranged from 2 month to 5 years old and between 30 and 50 years old for adults. The average of discharged greywater ranged from 80 to $200 \mathrm{~L} \mathrm{day}^{-1}$ with $73.1 \mathrm{~mL} \mathrm{~min}^{-1}$ of the flow rate. About $60-150 \mathrm{~L}$ were generated from 2 to 3 times bathing per day, while $20-50 \mathrm{~L}$ were produced from the cleaning process of the house and cloths; no kitchen wastewater were included in these quantities.
These findings are similar to that reported in provirus study which was conducted by Mohamed et al. [3] on different houses at the same region (Batu Pahat). Various cleaning products with different ingredients were used based on their availability in local market [13]. The common practice of greywater disposal is into the street drainage; these practices were also reported by Wurochekke et al. $[14,15]$.

\section{Quality of raw bathroom greywater}

The characteristics of raw greywater are presented in Table 3. It can be noted that the concentrations of COD, $\mathrm{BOD}_{5}$ and TSS exceeded the Environmental Quality Act 1974 (Regulation 2009) for disposal into the environment. The highest concentrations of $\mathrm{BOD}_{5}, \mathrm{COD}$ and TSS were recorded in houses 3 and $4 \quad(178 \pm 21.91$ vs. $134.25 \pm 66.20 ; 333.97 \pm 56.66$ vs. $308.41 \pm 195.06$ and $229.8 \pm 25.29$ vs. $248.6 \pm 42.62 \mathrm{mg} \mathrm{L}^{-1}$ ). BOD $_{5}$ concentrations were 9 and 3 fold compared to Standards A and $\mathrm{B}$, respectively, while COD concentrations were 6 and 3 fold compared to Standards A and B, respectively. The high values of $\mathrm{BOD}_{5}$ and $\mathrm{COD}$ in houses 3 and 4 might be due to the presence of children less than 1 year, besides the low quantities of greywater generated as compared with

Table 2 Summary of the household activities at four case studies extracted from the questionnaire

\begin{tabular}{|c|c|c|c|c|c|}
\hline Segment & Data & House 1 & Hous e 2 & Hous e 3 & Hous e 4 \\
\hline \multirow{5}{*}{$\begin{array}{c}\text { Demographic } \\
\text { Profile }\end{array}$} & No of residents & 4 & 3 & 4 & 4 \\
\hline & No of adults & II & & & \\
\hline & No of childrens & & & & \\
\hline & \multirow{2}{*}{ Age (y ears) } & 2 years & 8 months & 2 months & 1 y ears \\
\hline & & 5 y ears & & 4 years & 3 y ears \\
\hline \multirow{5}{*}{$\begin{array}{c}\text { Household } \\
\text { Practice } \\
\&\end{array}$} & Toilets inside & $\checkmark$ & $\checkmark$ & $\checkmark$ & $\checkmark$ \\
\hline & Frequency of & $2-3$ & 2 & $2-3$ & $2-3$ \\
\hline & taking bath per day & & & & \\
\hline & \multicolumn{4}{|c|}{ Personal care products } & \\
\hline & Shampoo & Dove & Rejoice & Head\&shoulder & Sunsilk \\
\hline \multirow{6}{*}{$\begin{array}{l}\text { Products } \\
\text { Preference }\end{array}$} & Shower gel & Lux & Johnson baby & Lifebuoy & Shokubutsu \\
\hline & & & Antabac & & \\
\hline & Toothpaste & Colgate & Safi & Fresh\&white & Colgate \\
\hline & Skincare & Fair\&lovely & Rice Milk & Nivea \& safi & Nivea \\
\hline & Bathroom cleaning & Harpic & Breeze & Ajax & Ajax \\
\hline & products & & (detergent) & & \\
\hline \multirow{6}{*}{$\begin{array}{l}\text { Greywater } \\
\text { Generation }\end{array}$} & Water consumed & 200 & 80 & 150 & 100 \\
\hline & per day $(\mathrm{L})$ & & & & \\
\hline & Activities & & & & \\
\hline & & 150 ltrs $\quad 50$ ltrs & 60 ltrs 201 ltrs & $\begin{array}{l}\text { 120ltrs } 301 \text { trs } \\
\text { 120le }\end{array}$ & $\begin{array}{c}1:: \\
801 t r s \\
\end{array}$ \\
\hline & Greywater disposal & street drainage & street drainage & street drainage & street drainage \\
\hline & method & & & & \\
\hline
\end{tabular}


Table 3 Characteristics of raw greywater collected from four house located at Parit Raja, Johor in the period between August 2015 to April 2016 $(n=12)$

\begin{tabular}{|c|c|c|c|c|c|c|}
\hline \multirow[t]{2}{*}{ Parameters } & \multicolumn{4}{|c|}{ Source of greywater samples } & \multicolumn{2}{|c|}{ Environmental quality Act 1974 (Regulation 2009) } \\
\hline & House 1 & House 2 & House 3 & House 4 & Standards A & Standards B \\
\hline $\mathrm{pH}$ & $6.51 \pm 0.66$ & $6.58 \pm 0.60$ & $6.56 \pm 0.63$ & $6.69 \pm 0.54$ & $6.0-9.0$ & $5.5-9.0$ \\
\hline $\mathrm{BOD}_{5}$ & $117.43 \pm 43.7$ & $151 \pm 22.99$ & $178 \pm 21.91$ & $134.25 \pm 66.20$ & 20 & 50 \\
\hline COD & $267.09 \pm 94.60$ & $221.08 \pm 84.58$ & $333.97 \pm 56.66$ & $308.41 \pm 195.06$ & 50 & 100 \\
\hline TSS & $184 \pm 37.33$ & $192.6 \pm 26.37$ & $229.8 \pm 25.29$ & $248.6 \pm 42.62$ & 50 & 100 \\
\hline Turbidity & $55.68 \pm 28.26$ & $63.74 \pm 43.81$ & $55.58 \pm 36.84$ & $60.06 \pm 23.76$ & NA & NA \\
\hline $\mathrm{NO}_{3}^{-}$ & $3.13 \pm 0.21$ & $3.82 \pm 0.48$ & $4.16 \pm 1.75$ & $6.86 \pm 4.33$ & 10 & 20 \\
\hline $\mathrm{PO}_{4}{ }^{3-}$ & $3.85 \pm 1.27$ & $4.12 \pm 1.25$ & $3.30 \pm 1.03$ & $3.15 \pm 0.94$ & 5 & 10 \\
\hline $\mathrm{NH}_{3}$ & $1.96 \pm 1.00$ & $2.03 \pm 1.28$ & $1.96 \pm 0.89$ & $2.88 \pm 1.22$ & NA & NA \\
\hline $\mathrm{Na}$ & $249.69 \pm 2.2$ & $104.78 \pm 1.58$ & $111.63 \pm 6.32$ & $154.59 \pm 4.59$ & NA & NA \\
\hline $\mathrm{Ca}$ & $16.11 \pm 2.54$ & $15.22 \pm 2.25$ & $17.25 \pm 3.85$ & $19.28 \pm 6.41$ & NA & NA \\
\hline $\mathrm{K}$ & $139.38 \pm 9.79$ & $114.16 \pm 3.84$ & $132.12 \pm 4.06$ & $135.46 \pm 4.48$ & NA & NA \\
\hline
\end{tabular}

All parameters unit are expressed in $\mathrm{mg} \mathrm{L}^{-1}$ except for $\mathrm{pH}$ and turbidity (NTU), biological oxygen demand (BOD5), chemical oxygen demand (COD), total suspension solids (TSS), nitrate $\left(\mathrm{NO}_{3}{ }^{-}\right)$, phosphate $\left(\mathrm{PO}_{4}{ }^{3-}\right)$, sodium (Na), calcium (Ca), potassium (K); Standards A: discharge upstream of water supply sources; Standards B: discharge downstream of water supply sources

NA not available

house 1 (150 and 100 vs. $200 \mathrm{~L})$ which has no children less than 1 year old. Utilization of low amount of water for bathing and washing leads to concentrate chemical substances in greywater and thus its parameters. The situation was similar to that reported by Casanova et al. [16] where turbidity and $\mathrm{BOD}_{5}$ were high in the household that consists of two adults and one child than household with no children. Moreover, the mean concentrations of COD and TSS in this study are within the range reported in grey water by Mohamed et al. [4]. Both $\mathrm{COD}$ and $\mathrm{BOD}_{5}$ are used as an indicator to evaluate the wastewater quality $[3,15]$. Its used to express the chemical and biological reaction level between the organic pollutants. The wastewater with high COD is associated with low dissolved oxygen and $\mathrm{pH}$ values, and affects negatively the survival of aquatic organisms. The main source of TSS in greywater is the clothes washing and cleaning dirty floors [10].

The concentrations of nutrients (total nitrogen and phosphorus) were within the Environmental Quality Act 1974 (Regulation 2009). $\mathrm{NO}_{3}{ }^{-}$ranged from $3.13 \pm 0.21$ to $6.86 \pm 4.33 \mathrm{mg} \mathrm{L}^{-1}$, while $\mathrm{PO}_{4}{ }^{3-}$ was between $3.15 \pm 0.94$ and $4.12 \pm 1.25 \mathrm{mg} \mathrm{L}^{-1}$. Na and $\mathrm{K}$ elements were quite high in the greywater, but no standard limits are regulated for these elements. These results are in agree with that reported by Wurochekke et al. [14] who found that the $\mathrm{NH}_{3}{ }^{-}$in households greywater was in average of $3.83 \mathrm{mg} \mathrm{L}^{-1}$. It has to mention that most of the nitrogen and phosphorus from households are contained in the urine which should go together with faces in the black water. However, the presence of a detectable concentrations of nitrogen and phosphate in this study would be coming from the bathing of children who might pass urine in their cloths or during the bathing. In all cases, the presence of nutrients even at low concentrations lead to occurrence of eutrophication phenomenon and algae bloom in the water. This is because the nutrient concentrations reported in this study are within the range $\left(5.47-13.83 \mathrm{mg} \mathrm{L}^{-1}\right)$ required for algae growth [17]. $\mathrm{Na}, \mathrm{Ca}$ and $\mathrm{K}$ represent very important elements for algae growth; therefore, the presence of these elements in the greywater might increase the potential of algae to overgrow and thus more negative effects on the quality of natural water.

\section{Phycoremediation process of greywater}

The efficiency of phycoremediation process using Botryococcus sp. to reduce the main parameters of greywater including $\mathrm{BOD}_{5}$ and $\mathrm{COD}$ as well as nutrients (TN and $\mathrm{TP}$ ) and basic elements ( $\mathrm{Na}, \mathrm{Ca}$ and $\mathrm{K}$ ) was investigated in the current study. The process was carried out for 21 days according to the references in literature indicating that the phycoremediation process takes place between 3 and 26 days to reduce nutrients and metals to minimum levels $[1,18]$.

Botryococcus sp. cell numbers in greywater were tested daily. The initial concentrations of inoculum were $10^{6}$ cell $\mathrm{mL}^{-1}$, and the growth rate was expressed in cells $\mathrm{min}^{-1}$. The growth curve is presented in Fig. 2. It was found that Botryococcus sp. growth curve appears similar to be in four phases, in the lag phase (1-2 days), the growth rate in greywater was in the average of 54 cell $\mathrm{min}^{-1}$, 
Fig. 2 Botryococcus sp. growth rate in the greywater during the phycoremediation process by using Botryococcus sp. $\left(0.3\right.$ g dry wt $\left.\mathrm{L}^{-1}\right)$. The experiments were conducted in $5 \mathrm{~L}$ tank capacity under normal environment conditions (temperature: $25-29^{\circ} \mathrm{C}, 12 \mathrm{~h} \mathrm{~L}$ : $12 \mathrm{~h} \mathrm{D}$ period) for 21 days. The control sample was carried out using $1 \mathrm{~L}$ of Bold's Basal Medium (BBM) broth

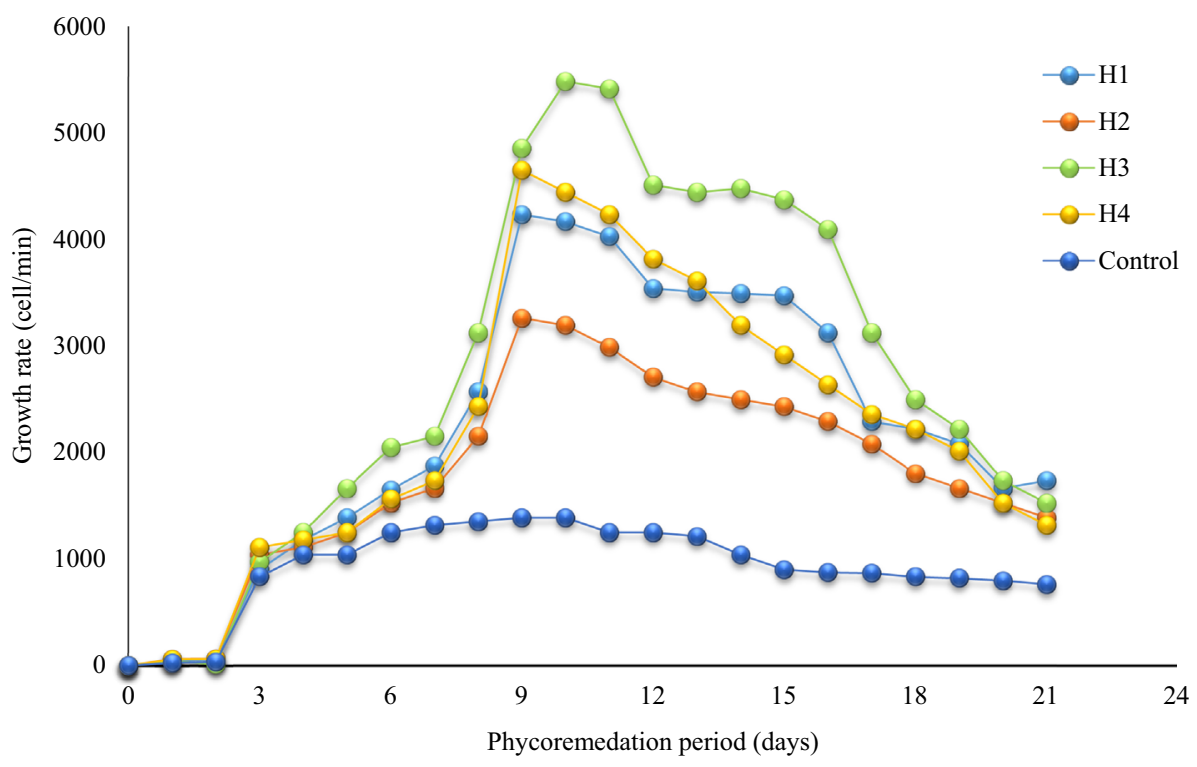

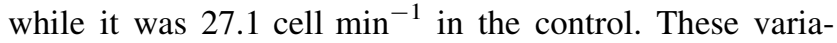
tions between the initial concentrations and after the incubation for 2 days as well as between greywater medium and BBM might be related to the adaption process. Botryococcus sp. was acclimatized to grow in greywater; therefore, the cell concentrations decreased slightly by only $10 \%$ compared to the initial concentrations. In the control, the dropping was quite more; the decrease was $40 \%$, because BBM has different composition to the greywater. Hence, microalgae need more time to acclimatize in this medium.

The log phase started on 3rd day, and the growth rate accelerated in the period between 6th and 9th day. The highest growth rate of microalgae was recorded on 9th day in greywater from house 1 (4236.1 cell $\left.\mathrm{min}^{-1}\right)$, house 2 $\left(3263.9\right.$ cell $\left.\mathrm{min}^{-1}\right)$ and house 4 (4652.8 cell $\left.\mathrm{min}^{-1}\right)$, while it was recorded on 10th day in greywater from house 3 (5486.1 cell $\left.\mathrm{min}^{-1}\right)$. Similar trend was observed for microalgae in the control where the maximum growth rate was 1388.89 cell $\mathrm{min}^{-1}$ on 9 th and 10th day. A stationary phase appeared clearly for microalgae growth in the control medium in the period between 15 th and 21 st day, while it was varied in the greywater. A semi-stationary phase was noted between 12 th and 15 th day of greywater from houses 1 and 3. The minimum growth rate of Botryococcus sp. was recorded on 21st day; the growth rate was 1736.1, 1388.9, 1527.8 and 1319.5 cell $\mathrm{min}^{-1}$ for greywater from houses 1 , 2, 3 and 4, respectively. It might be due to the depletion in the essential nutrient and increased the total mass of microalgae which prevent the light penetration required for photosynthesis process [19, 20].

Finally, the highest growth rate of Botryococcus sp. during the phycoremediation process was noted in greywater from house 3 followed by that obtained from house 4 . The minimum growth rate was noted in greywater from house 2. The explanations for these results might be related to the concentrations of elements in the greywater samples presented in Table 3, where the greywater from house 2 recorded the lowest concentrations of $\mathrm{Na}, \mathrm{Ca}$ and $\mathrm{K}$. These findings indicate the role of elements in microalgae growth induction [21]. However, microalgae need these macronutrients in low concentrations and they were available in amounts enough to induce the Botryococcus sp. growth. Hence, the turbidity might be the more acceptable reason, where the maximum turbidity was recorded in greywater from house 2 and the quantity of greywater from this house was the lowest $\left(80 \mathrm{~L} \mathrm{day}^{-1}\right)$. The high turbidity might limit the light penetration through the greywater and thus reduce the photosynthesis level of the microalgae. The light is one of the main factors affecting microalgae growth because macroalgae cell converts the light into energy via the photosynthesis process and the microalgae cell has no mechanism to store the light [1, 22].

Bathroom greywater $\mathrm{pH}$ was alkaline due to the use of soaps and detergents and it increased significantly during the phycoremediation process (Fig. 3). The maximum $\mathrm{pH}$ value was recorded on 9th day; it ranged from 9 to 10.5 in the greywater while it was 8.9 in the control. The increase in $\mathrm{pH}$ value is in consistent with the growth rate of Botryococcus sp. which recorded the maximum rate on 9 and 10th day. It has demonstrated before that the $\mathrm{pH}$ range for most algal species is between 7 and 9. However, it has to be indicated that the $\mathrm{pH}$ is not critical or it is an independent factor that might be varied during the phycoremediation process depending on the availability of $\mathrm{CO}_{2}$, $\mathrm{H}_{2} \mathrm{CO}_{3}$, and $\mathrm{HCO}_{3}{ }^{-}$[23]. Therefore, $\mathrm{pH}$ is a secondary 
Fig. $3 \mathrm{pH}$ values of greywater samples collected from four houses during the phycoremediation process by using Botryococcus sp. $\left(0.3 \mathrm{~g}\right.$ dry wt $\left.\mathrm{L}^{-1}\right)$. The experiments were conducted in 5 L tank capacity under normal environment conditions (temperature: $25-29^{\circ} \mathrm{C}, 12 \mathrm{~h} \mathrm{~L}$ : $12 \mathrm{~h} \mathrm{D}$ period) for 21 days. The control sample was carried out without Botryococcus sp. inoculation

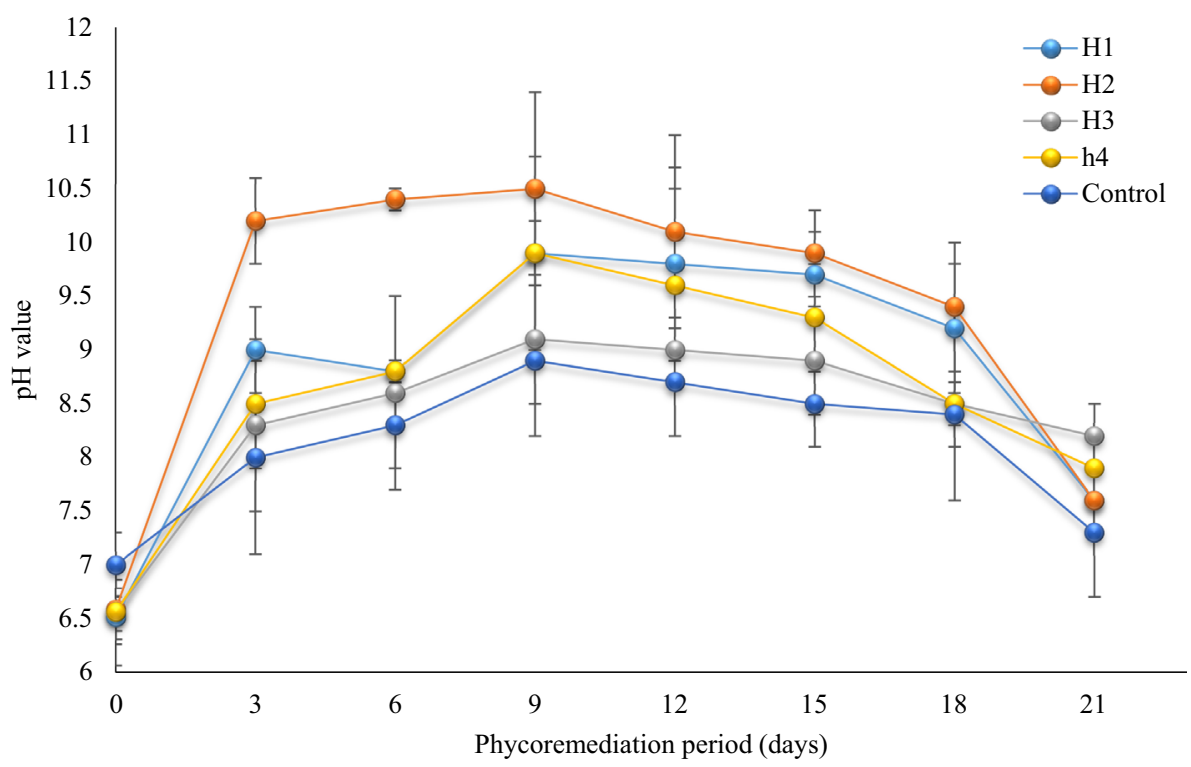

factor with less effects on the microalgae growth if the nutrients are available.

The reduction in COD of greywater during the phycoremediation process is depicted in Fig. 4a. It appeared that the reduction of COD increased alongside the phycoremediation period to 21 days, where the maximum reduction ranged from 71.22 to $85.47 \%$, while it was $10.4 \%$ in the control (without inoculum). Among four types of greywater, the highest reduction was noted in greywater from house 4 followed by that from house 2 and house 3 ; the minimum reduction was observed in greywater from house 1. These findings demonstrated the potential of Botryococcus sp. to degrade chemical and detergents substances in the greywater which contribute to the presence of high COD concentrations. The significant $(P<0.01)$ differences between the reduction percentages of COD by Botryococcus sp. among four types greywater might be related to the type of detergents and products used for bathing, where the microalgae have high potential to degrade some types more efficiency than others. However, the reduction percentage recorded here is more than that noted using granular activated carbon (GAC) biofilm reactor and sand filter system which was reported by AlMughalles et al. [24] (85.47 vs. 65\%, respectively), but still less than that recorded using a free water surface flowconstructed wetland (FWS-CW) with a three-compartment septic system which was $91 \%$ [25]. Nonetheless, the easy implementable and maintenance of the phycoremediation system design here has more advantages compared to FWS-CW.

The reduction of $\mathrm{BOD}_{5}$ is increased significantly $(P<0.05)$ upward during the phycoremediation process (Fig. 4b). The maximum reductions were 85.3, 98, 94.4 and $90 \%$ in greywater from houses 1 to 4 , respectively. It was noted that the reduction in $\mathrm{BOD}_{5}$ in greywater from house 2 was less than that from others house during the phycoremediation process for 18 days. However, at 21 st day, it was the highest reduction; this note was also recorded for COD. The explanation for these findings might be due to the types of chemical substances in detergents which have long persistence time as compared to that available in greywater from others houses. In comparison to the control where the maximum reduction is $10.3 \%$, it can be indicated that Botryococcus sp. has the high potential to reduce $\mathrm{BOD}_{5}$ more efficient than the FWS-CW reported by Gunes et al. [25] as well as that by filtration-adsorption systems reported by Nnaji et al. [26], where the highest reduction was 91 and $85.68 \%$, respectively, while the maximum reduction in this study was $98 \%$.

The reduction of nutrients in four types of greywater is presented in Fig. 5. $\mathrm{NO}_{3}{ }^{-}$in four types of greywater has reduced by $98 \%$ after 18 days of the phycoremediation process, while it was $8.7 \%$ in the control (Fig. 5a). $\mathrm{NH}_{3}{ }^{-}$ was reduced by $86.21-99 \%$ after 21 days. The maximum reduction was recorded among greywater from houses 1 and 3 (Fig. 5b). The results revealed the reduction in $\mathrm{NO}_{3}{ }^{-}$ associated with increase in the $\mathrm{pH}$ values during the period from 3 to 15 days. In contrast, the reduction of $\mathrm{NH}_{3}{ }^{-}$ correlated with decreases in $\mathrm{pH}$ where $\mathrm{pH}$ started to decline after 15 th day and reached the lowest value on 21 st at which the reduction of $\mathrm{NH}_{3}{ }^{-}$recorded the highest percentage. The results also showed that the reduction of $\mathrm{NO}_{3}{ }^{-}$was faster than $\mathrm{NH}_{3}{ }^{-}$. These findings are inconsistent with other studies which revealed that the $\mathrm{NO}_{3}{ }^{-}$is the preferred form of nitrogen source for microalgae cells; the utilization of $\mathrm{NO}_{3}{ }^{-}$leads to rise the $\mathrm{pH}$ values. Conversely, utilization of ammonia is associated with the releasing of 
Fig. 4 Reduction of COD and BOD concentrations in greywater samples collected from four houses during the phycoremediation process using Botryococcus sp.

(0.3 g dry wt $\left.\mathrm{L}^{-1}\right)$. The experiments were conducted in $5 \mathrm{~L}$ tank capacity under normal environment conditions (temperature: $25-29^{\circ} \mathrm{C}, 12 \mathrm{~h} \mathrm{~L}$ : $12 \mathrm{~h}$ D period) for 21 days. The control sample was carried out without Botryococcus sp. inoculation
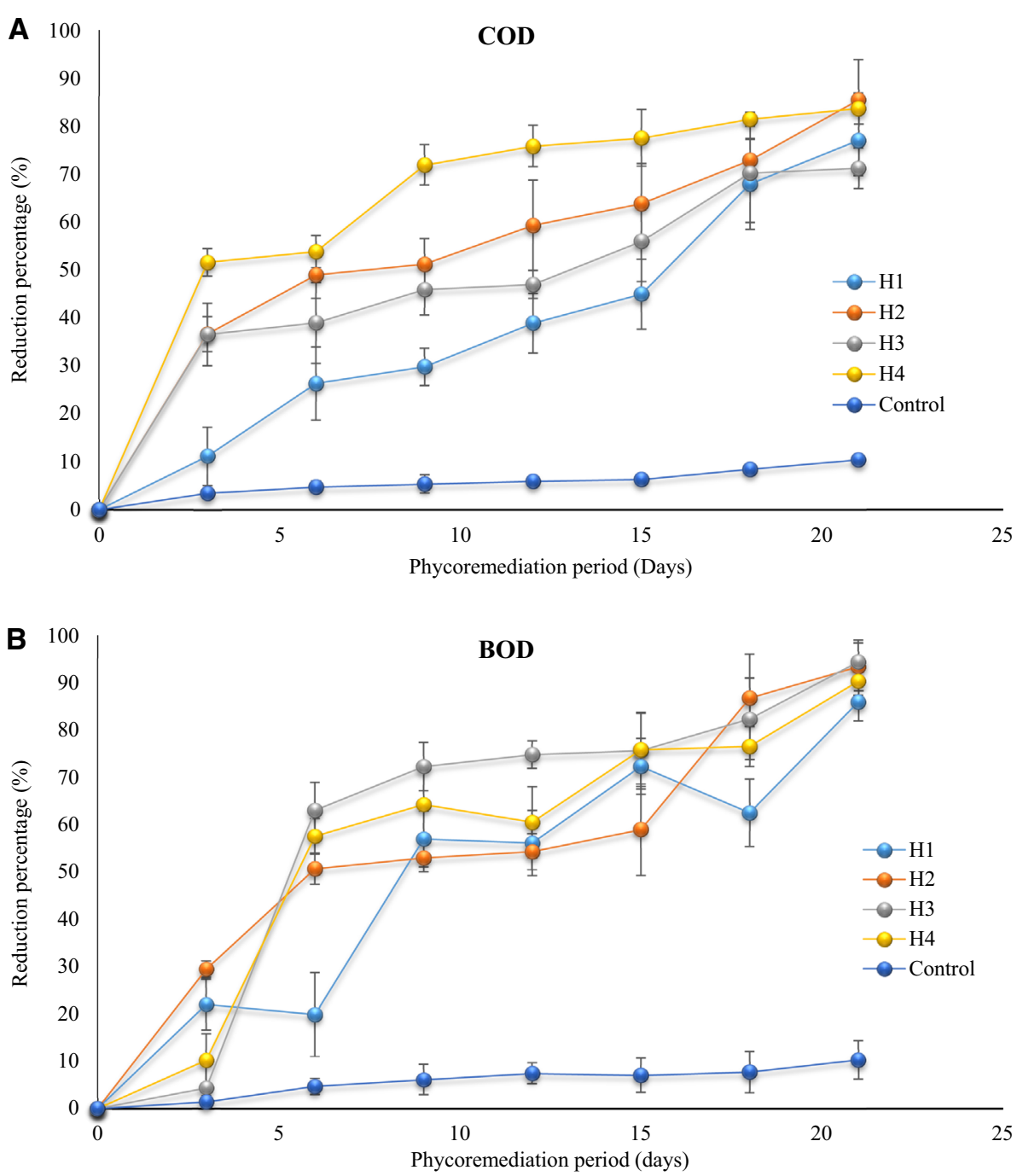

$\mathrm{H}^{+}$ions and thus drooping of $\mathrm{pH}$ values [27]. The reduction obtained here is more than that reported by Gani et al. [7], where the maximum reduction of $\mathrm{TN}$ from household greywater in Malaysia by B. braunii was $52 \%$. These differences might be due to the starvation process conducted in the current work which induced the microalgae growth and thus the reduction efficiency. Silambarasan et al. [28] performed a similar process for Pithophora sp. where it was separated from the culture media and dried before utilization in the reduction of nitrogen and phosphorus. The study revealed high growth of Pithophora sp. with 97 and $99 \%$ of removal of TN and TP within 20 days of treatment.

The reduction of $\mathrm{PO}_{4}{ }^{3-}$ increased gradually in the first 15 th day and then accelerated in the period between 15 and 21 days (Fig. 6c). The maximum removal was obtained for greywater from house $1(99.3 \%)$, followed by greywater from house $2(82.57 \%)$ and house $3(76.86 \%)$. The lowest reduction was noted in greywater from house $4(39.12 \%)$. The maximum reduction in the control sample was $8.4 \%$. The results reported here are in agreement with Gokulan et al. [29] who revealed that $B$. Braunii reduce TN and TP by 97.82 and $77.52 \%$ from greywater in India. Moreover, Botryococcus sp. investigated here exhibited high efficiency for reducing TP from greywater with percentage reached $99.3 \%$, indicting the effectiveness of phycoremediation process investigated in the present study.

It has revealed in the literature that most microalgae species have high potential to remove nutrients by assimilation process, but the removal efficiency of nitrogen is more than that for phosphorous due to the role of nitrogen in the anabolism pathway of microalgae cells [1]. Nitrogen represents a building unit for amino acids, chlorophyll as well as DNA and RNA material [30]. Both $\mathrm{NO}_{3}$ and $\mathrm{NH}_{3}$ are taken by diffusion through cell membrane due to the low molecular weight which facilitates the transmission by passive uptake transport system. Phosphorus $(\mathrm{P})$ is available in the greywater in orthophosphate $\left(\mathrm{PO}_{4}{ }^{3-}\right)$ form, but the microalgae cells have to degrade the organic matter and release phosphate by the hydrolysis enzymes such as phosphoresterases or phosphatases to be dissolved in water 
Fig. 5 Reduction of nutrients concentrations in greywater samples collected from four houses during the

phycoremediation process using Botryococcus sp.

$\left(0.3\right.$ g dry wt $\left.\mathrm{L}^{-1}\right)$. The experiments were conducted in $5 \mathrm{~L}$ tank capacity under normal environment conditions (temperature: $25-29^{\circ} \mathrm{C}, 12 \mathrm{~h} \mathrm{~L}$ : $12 \mathrm{~h}$ D period) for 21 days. The control sample was carried out without Botryococcus sp. inoculation
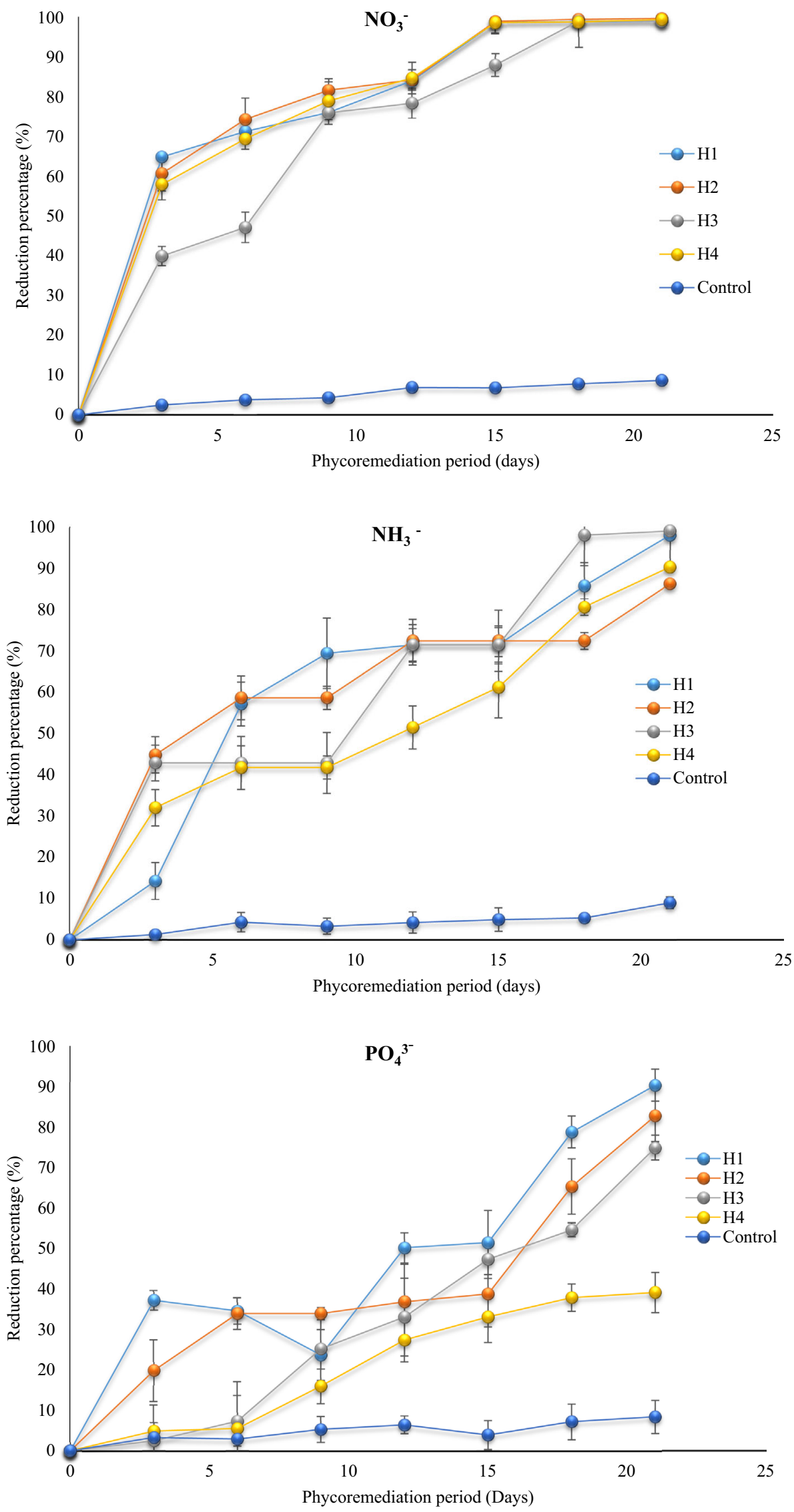
Fig. 6 Removal of elements from greywater samples collected from four houses during the phycoremediation process using Botryococcus sp. (0.3 g dry wt $\left.\mathrm{L}^{-1}\right)$. The experiments were conducted in $5 \mathrm{~L}$ tank capacity under normal environment conditions (temperature: $25-29^{\circ} \mathrm{C}, 12 \mathrm{~h} \mathrm{~L}$ : $12 \mathrm{~h} \mathrm{D}$ period) for 21 days. The control sample was carried out without Botryococcus sp. inoculation
$\mathbf{K}$
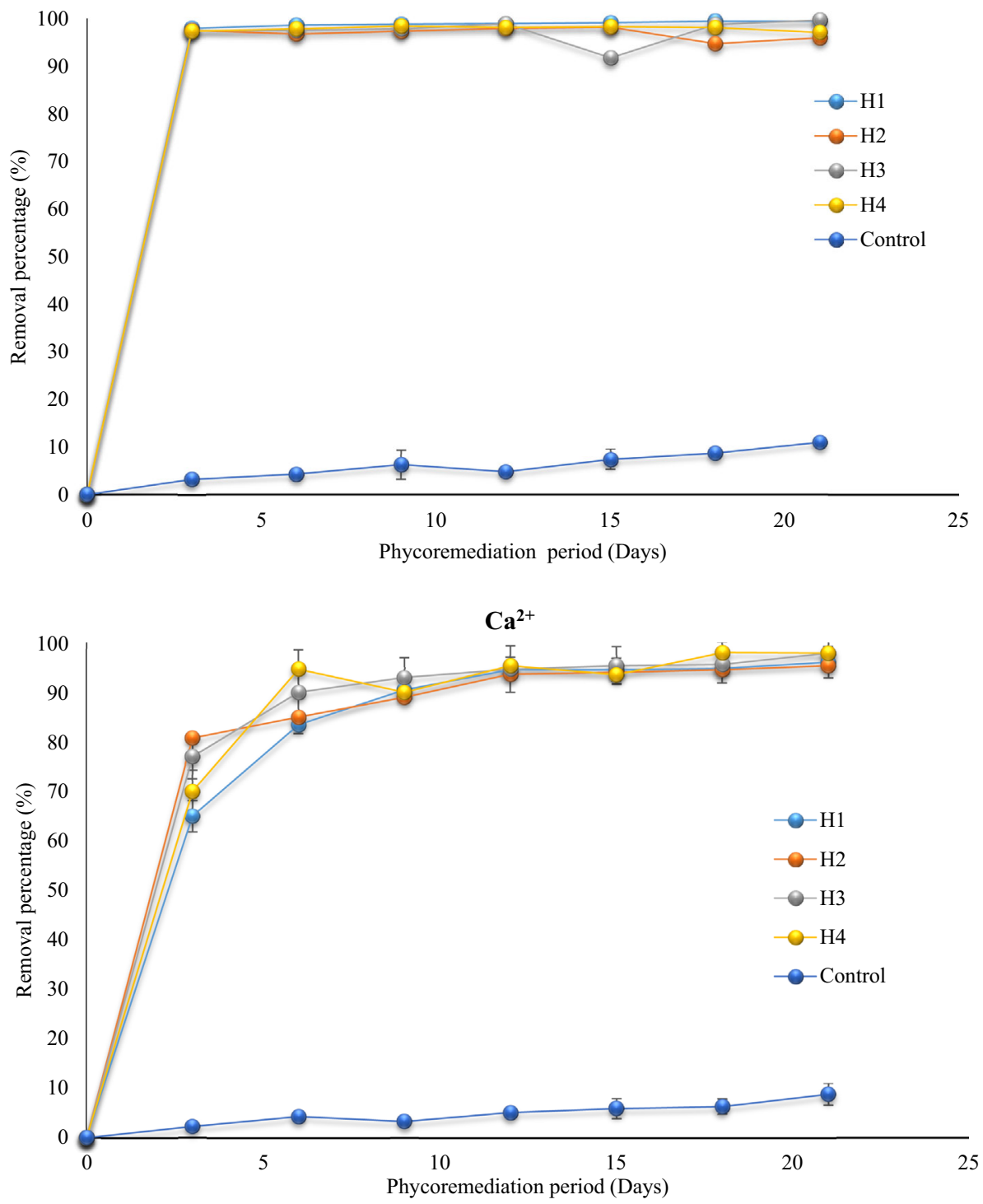
and the uptake by the cells via assimilation process [22]. The low reduction of $\mathrm{PO}_{4}{ }^{3-}$ from greywater of house 4 might be due to the structure of chemical substance in the detergents and soaps which have more persistence to the degradation process as mentioned above.

Botryococcus sp. exhibited high efficiency for removal of elements; it has removed more than $97 \%$ of $\mathrm{K}$ for four types of greywater within 3 days of the phycoremediation period (Fig. 6a). Ca was also removed rapidly, where more than $95 \%$ of the removal from different greywater was recorded on 12th day. In contrast, the removal of $\mathrm{Na}$ from greywater increased gradually and differed significantly $(P<0.05)$ among the greywater samples from different houses (Fig. 6c). The maximum removal was noted on 21 st day where $93.47,89.31,63.89$ and $58.32 \%$ were removed from greywater of houses 3, 1, 4 and 2, respectively. The maximum removal of $\mathrm{K}, \mathrm{Ca}$ and $\mathrm{N}$ from control sample was less than $10 \%$. The ability of microalgae to accumulate different types of metals ions has been reported in the literature and explained due to the presence of functional groups on the cell wall and cell membrane of microalgae cells which react with metal ions to form complex compounds [31]. Microalgae cells removed metal ions by chemisorption, surface precipitation, ion exchange, and covalent bonding [32]. The metal ions could be also diffused through the cell membrane via passive transport system where they play important roles in the metabolic and anabolic pathways of the microalgae cells.

The reduction of the greywater by Botryococcus sp. used in the present study is more than that reported in the literature. Gani et al. [7] revealed that B. braunii reduced BOD, COD and TN in the greywater in Malaysia by 82,88 and $52 \%$, respectively, as well as the resulted reported by Gokulan et al. [29] who found that Botryococcus sp. reduced BOD and COD in greywater from Men hostel by 66.7 and COD $85.6 \%$, respectively. Liu et al. [18] concluded that Botryococcus sp. reduce TP and TN in Aerated Swine wastewater in China by 93.3 and $40.8 \%$, respectively. The high efficiency of Botryococcus sp. noted in this study might be related to the starvation process which accelerated the potential of Botryococcus sp. for the assimilation of nutrients and soluble organic matter.

It should indicate that despite the growth rate of Botryococcus sp. has declined after the 9th day of the phycoremediation process of greywater from houses 1, 2 and 4 and after 12th day in greywater from house 3 , the reduction percentage of $\mathrm{COD}, \mathrm{BOD}_{5}$, nutrients and elements has increased. This could be explained due to the reduction capacity $\left(Q_{\max }\right)$ for the microalgae cells. $Q_{\max }$ represents the amount of pollutant removed by microalgae cells. The results found that the $Q_{\max }$ for each microalgae cell increased with decrease in the growth rate. For example, the $Q_{\max }$ for reduction COD at 9 th day was $0.094 \mathrm{mg}$ per growth rate $\left(4236.1 \mathrm{cell} \mathrm{min}^{-1}\right)$, and increased to $0.56 \mathrm{mg}$ per growth rate $\left(1736.1 \mathrm{cell}^{-1}\right)$. There are no maximum and minimum $Q_{\max }$ reported in literature, but the increase in the reduction percentage showed in this study indicates that the microalgae cell has high reduction capacity for the greywater parameters.

\section{Characteristics of treated greywater}

The characteristics of greywater generated after 21 days of the phycoremediation process are illustrated in Table 4. It can be noted that the $\mathrm{BOD}_{5}$ has dropped to meet Environmental

Table 4 Characteristics of treated greywater after phycoremediation using Botryococcus sp. $\left(0.3 \mathrm{~g}\right.$ dry wt $\left.\mathrm{L}^{-1}\right)$

\begin{tabular}{|c|c|c|c|c|c|c|}
\hline \multirow[t]{2}{*}{ Parameters } & \multicolumn{4}{|c|}{ Source of greywater samples } & \multicolumn{2}{|c|}{ Environmental quality Act 1974 (Regulation 2009) } \\
\hline & House 1 & House 2 & House 3 & House 4 & Standards A & Standards B \\
\hline $\mathrm{pH}$ & $7.60 \pm 0.34$ & $7.60 \pm 0.42$ & $8.20 \pm 0.61$ & $7.90 \pm 0.32$ & $6.0-9.0$ & $5.5-9.0$ \\
\hline $\mathrm{BOD}_{5}$ & $16.50 \pm 3.22$ & $10.00 \pm 2.5$ & $10 \pm 1.1$ & $13.00 \pm 2.6$ & 20 & 50 \\
\hline COD & $61.34 \pm 5.3$ & $52.08 \pm 4.2$ & $96.07 \pm 7.43$ & $134.26 \pm 5.4$ & 50 & 100 \\
\hline $\mathrm{NO}_{3}^{-}$ & $0.03 \pm 0.00$ & $0.01 \pm 0$ & $0.28 \pm 0.1$ & $0.03 \pm 0$ & 10 & 20 \\
\hline $\mathrm{PO}_{4}^{3-}$ & $0.37 \pm 0.0 .1$ & $0.71 \pm 0.12$ & $0.83 \pm 0.8$ & $1.92 \pm 0.03$ & 5 & 10 \\
\hline $\mathrm{NH}^{3}$ & $0 \pm 0$ & $0.28 \pm 0.2$ & $0.28 \pm 0.09$ & $1.3 \pm 1.1$ & NA & NA \\
\hline $\mathrm{Na}$ & $27.46 \pm 1.5$ & $40.83 \pm 4.2$ & $7.28 \pm 2.2$ & $55.82 \pm 4.6$ & NA & NA \\
\hline $\mathrm{Ca}$ & $0.63 \pm 0.21$ & $0.70 \pm 0.2$ & $0.36 \pm 0.22$ & $0.42 \pm 0.2$ & NA & NA \\
\hline $\mathrm{K}$ & $4.14 \pm 0.98$ & $4.07 \pm 1.8$ & $4.12 \pm 1.2$ & $4.32 \pm 1.9$ & NA & NA \\
\hline
\end{tabular}

The experiments were conducted in $5 \mathrm{~L}$ tank capacity under normal environment conditions (temperature: $25-29^{\circ} \mathrm{C}, 12 \mathrm{~h} \mathrm{~L}: 12 \mathrm{~h} \mathrm{D}$ period) for 21 days $(n=12)$

All parameters unit are expressed in $\mathrm{mg} \mathrm{L}^{-1}$ except for $\mathrm{pH}$; biological oxygen demand (BOD5), chemical oxygen demand (COD), nitrate $\left(\mathrm{NO}_{3}{ }^{-}\right)$, phosphate $\left(\mathrm{PO}_{4}{ }^{3-}\right)$, sodium $(\mathrm{Na})$, calcium $(\mathrm{Ca})$, potassium $(\mathrm{K})$; Standards A: discharge upstream of water supply sources; Standards B: Discharge downstream of water supply sources

NA not available 
Quality Act 1974 (Regulation 2009), Standards A, while COD met Standards B. Nutrients have reduced to the minimum concentrations. The final concentrations of $\mathrm{NO}_{3}{ }^{-}$and $\mathrm{PO}_{4}{ }^{3-}$ ranged from 0.01 to 0.28 and 0.37 to $1.92 \mathrm{mg} \mathrm{L}^{-1}$, respectively, which is within the range recommended by EQA1974 (10 and $5 \mathrm{mg} \mathrm{L}^{-1}$, respectively). There are no standards limits required for $\mathrm{NH}^{3}$ as well as $\mathrm{Na}, \mathrm{Ca}$ and $\mathrm{K}$ ions. However, the removal of $\mathrm{NH} 3$ ranged from 60 to $100 \%$. The concentrations of $\mathrm{Na}, \mathrm{Ca}$ and $\mathrm{K}$ ions reduced by more than $90 \%$ to be available with microelements concentrations range. $\mathrm{pH}$ of the treated greywater was neutral which is more suitable for reuse in the irrigation.

The greywater could be discharged without secondary effects on the environment. These results indicate that the phycoremediation process conducted in this study has high efficiency and might be used by the individual house for the treatment of greywater. In comparison with others system, Mohamed et al. [3] investigated the efficiency of a multicomponent filtration system for the treatment of greywater at village house. The study reported that the filtrated greywater meet Standards A, in terms of $\mathrm{BOD}_{5}$, COD and TSS. Moreover, the filtration system is not effective for removal of nutrients, while the phycoremediation system suggested here have exhibited high effectiveness for nutrients removal.

The application of phycoremediation system at village house needs two tanks (storage and bioreactor tank). The maximum quantity of greywater estimated in this study was $200 \mathrm{~L}$ days and the maximum incubation period of phycoremediation process was 21 days with $4200 \mathrm{~L}$ of quantity. Therefore, the capacity of storage tank is supposed to be $2100 \mathrm{~L}$, while more than one phycoremediation tank can be used with a total capacity of $2100 \mathrm{~L}$. The flowrate of the greywater into the phycoremediation tank would be $139 \mathrm{~mL} \mathrm{~min}{ }^{-1}$. As shown in Fig. 2 the flow of greywater from the storage tank into phycoremediation tank is happened seamlessly without water pump. Besides, the process might provide air bubbles which might be used as alternative for air pump. Based on that, it can be indicated that no energy is required for the performance the phycoremediation system; this advantage might induce the people at village houses to apply for this system. Botryococcus sp. was used as a dry mass to facility the utilization by the people in the village houses and it need to be inoculated only at the fixation of phycoremediation system due to semi-continuous operation of this process.

\section{Conclusion}

The objective of the current work was to examine the applicability of Botryococcus sp. for improving the characteristics of bathroom greywater before the final disposal into the environment. Botryococcus sp. exhibited high efficiency for reducing $\mathrm{BOD}_{5}$ to comply with Standards limits required for the environmental disposal $\left(<20 \mathrm{mg} \mathrm{L}^{-1}\right)$. Moreover, it has the ability to reduce COD to meet the Standards limits $\left(100 \mathrm{mg} \mathrm{L}^{-1}\right)$ in $75 \%$ of the samples after 21 days. The results recorded rapidly reduction of $\mathrm{NO}_{3}{ }^{-}$within 18 days with $98 \%$ of the efficiency. In comparison, the highest reduction of ammonia $\left(\mathrm{NH}_{3}\right)$ and orthophosphate $\left(\mathrm{PO}^{3-}{ }^{3-}\right)$ was 99 and $99.3 \%$, respectively recorded after 21 days. It can be concluded that the phycoremediation process system investigated here exhibited high effectiveness for the treatment of greywater from village houses. The process would limit the level of contamination discharged with greywater into the environment. The system is more applicable to be used at village house because it is easily implementable, very low cost where no energy is required, eco-friendly and has no toxic by-products. The application of this system for individual house would enhance the role of the community in maintaining a sustainable environment.

Acknowledgement The authors are grateful for the financial support provided by the Fundamental Research Grant Scheme (FRGS) Vot 1453 from the Ministry of Education, Malaysia.

Open Access This article is distributed under the terms of the Creative Commons Attribution 4.0 International License (http://creative commons.org/licenses/by/4.0/), which permits unrestricted use, distribution, and reproduction in any medium, provided you give appropriate credit to the original author(s) and the source, provide a link to the Creative Commons license, and indicate if changes were made.

\section{References}

1. Jais, N.M., Mohamed, R.M.S.R., Al-Gheethi, A.A., Hashim, M.A.: The dual roles of phycoremediation of wet market wastewater for nutrients and heavy metals removal and microalgae biomass production. Clean Technol Environ Policy 19(1), 37-52 (2017)

2. Al-Gheethi, A.A., Mohamed, R.M., Efaq, A.N., Amir, H.K.: Reduction of microbial risk associated with greywater utilized for irrigation. Water Health J. 14(3), 379-398 (2016)

3. Mohamed, R.M., Al-Gheethi, A.A., Jackson, A.M., Amir, H.K.: Multi component filters for domestic greywater treatment in village houses. J. Am. Water Works Ass (AWWA) 108(7), 405-414 (2016)

4. Mohamed, R.M., Chan, C.M., Senin, H., Kassim, A.H.: Feasiability of the direct filtration over peat filter media for bathroom greywater treatment. J. Water Environ. Sci. 5(6), 2021-2029 (2014)

5. IWK: Sewage treatment plant. Indah Water Konsortium Sdn Bhd. http://www.iwk.com.my/v/knowledge-arena/sewage-treatmentplant. Accessed on 10 Dec 2016

6. Abou-Shanab, R.A., Ji, M., Kim, H., Paeng, K., Jeon, B.: Microalgal species growing on piggery wastewater as a valuable candidate for nutrient removal and biodiesel production. J. Environ. Manag. 115, 257-264 (2013)

7. Gani, P., Sunar, N.M., Matias-Peralt, H.M.: Experimental study for phycoremediation of Botryococcus sp. on greywater. Appl. Mech. Mat. 773-774, 1312-1317 (2015) 
8. Sivasubramaniam, V.: Phycoremediation technology applied to effluent treatment. Retrieved August 20, 2013 at Phycoremediation (Remediation using algae). http://phycoremediation.in/pro jects.html (2013)

9. Rengefors, K., Karlsson, I., Hansson, L.A.: Algal cyst dormancy: a temporal escape from herbivory. Proc. R. Soc. B Biol. Sci. 265, 1353-1358 (1998)

10. American Public Health Association, Inc (APHA): Standard Methods for the Examination of Water and Wastewater, 21st edn. APHA, New York (2005)

11. Bischoff, H.W., Bold, H.C.: Some soil algae from enchanted rock and related algae species. Phycol. Stud. 44(1), 1 (1963)

12. Larsdotter, K., Jansen, J.L., Dalhammar, G.: Biologically mediated phosphorus precipitation in wastewater treatment with microalgae. Environ. Technol. 28(9), 953-960 (2007)

13. Jefferson, B., Palmer, A., Judd, S.: Grey water characterization and its impact on the selection. Water Sci. Technol. 50(2), 157-164 (2004)

14. Wurochekke, A.A., Mohamed, R.M.S., Al-Gheethi, A.A., Atiku, H., Amir, H.M., Matias-Peralta, H.M.: Household greywater treatment methods using natural materials and their hybrid system. J Water Health 14(6), 914-928 (2016)

15. Wurochekke, A.A., Harun, N.A., Mohamed, R.M.S.R., Kassim, A.H.B.M.: Constructed Wetland of Lepironia Articulata for household greywater treatment. APCBEE Procedia 10, 103-109 (2014)

16. Casanova, L.M., Little, V., Frye, R.J., Gerba, C.P.: A survey of the microbial quality of recycled household graywater. J. Am. Water Res. Assoc. 37, 1313-1320 (2001)

17. Chinnasamy, S., Bhatnagar, A., Hunt, R.W., Das, K.C.: Microalgae cultivation in a wastewater dominated by carpet mill effluents for biofuel applications. Bioresour. Technol. 101(9), 3097-3105 (2010)

18. Liu, J., Ge, Y., Cheng, H., Wu, L., Tian, G.: Aerated swine lagoon wastewater: a promising alternative medium for Botryococcus braunii cultivation in open system. Bioresour. Technol. 139, 190-194 (2013)

19. Zwietering, M.H., Jongenburger, I., Rombouts, F.M., van't Riet, K.: Modeling of the bacterial growth curve. Appl. Environ. Microbiol. 56(6), 1875-1881 (1990)

20. Devi, P., Subhash, M.G., Mohan, S.V.: Heterotrophic cultivation of mixed microalgae for lipid accumulation and wastewater treatment during sequential growth and starvation phases: effect of nutrient supplementation. Renew. Energy 43, 276-283 (2012)
21. Cavet, J., Borrelly, G., Robinson, N.: Zn, Cu, and $\mathrm{Co}$ in Cynobacteria; a selective control of metal availability. FEMS Microbial. Rev. 27, 165-181 (2003)

22. Atiku, H., Mohamed, R.M., Al-Gheethi, A.A., Wurochekke, A.A., Kassim A.H.: Harvesting microalgae biomass from the phycoremediation process of greywater. Environ. Sci. Poll. Res. (Online) (2016)

23. Yaakob, Z., Ali, E., Mohamad, M., Takrif, M.S.: An overview: biomolecules from microalgae for animal feed and aquaculture. J. Biol. Res. 21(6), 1-10 (2014)

24. Al-Mughalles, M.H., Abd-Rahman, R., Suja, F., Mahmud, M., Jalil, N.A.: Household greywater quantity and quality in Sana'a. Yemen. EJGE 17(2012), 1025-1034 (2012)

25. Gunes, K., Tuncsiper, B., Ayaz, S., Drizo, A.: The ability of free water surface constructed wetland system to treat high strength domestic wastewater: a Case Study for the Mediterranean. Ecol. Eng. J. 44, 278-284 (2012)

26. Nnaji, C.C., Mama, C.N., Ekwueme, A., Utsev, T.: Feasibility of a filtration-adsorption grey water treatment system for developing countries. Hydrol. Curr. Res. S1, 006 (2013). doi:10.4172/21577587.S1-006

27. Arumugam, M., Agarwal, A., Arya, A.C., Ahmed, Z.: Influence of nitrogen sources on biomass productivity of microalgae Scenedesmus bijugatus. Short communication. Bioresour. Technol. 131, 246-249 (2013)

28. Silambarasan, T., Vikramathithan, M., Dhandapani, R., Mukesh, D.J., Kalaichelvan, P.T.: Biological treatment of dairy effluent by microalgae. World J. Sci. Technol. 2(7), 132-134 (2012)

29. Gokulan, R., Sathish, N., Kumar, R.P.: Treatment of grey water using hydrocarbon producing Botryococcus braunii. Int. J. Chem. Tech. Res. 5(3), 1390-1392 (2013)

30. Knud-Hansen, C.F., Clair, D.: Pond fertilization: ecological approach and practical application. In: McElwee, K., Baker, J. (eds.) Corvallis, Oregon: Pond Dynamics/Aquaculture Collaborative Research Support Program, p. 112. Oregon State University (1998)

31. Al-Gheethi, A.A., Lalung, J., Efaq, A.N., Bala, J.D., Norli, I.: Removal of heavy metals and $\beta$-lactam antibiotics from sewage treated effluent by bacteria. Clean Technol. Environ. Policy 17(8), 2101-2123 (2015)

32. Muñoz, R., Guieysse, B.: Algal bacterial processes for the treatment of hazardous contaminants: a review. Water Res. 40(15), 2799-2815 (2006) 